Dokuz Eylül Üniversitesi-Mühendislik Fakültesi Fen ve Mühendislik Dergisi

Cilt 20, Sayı 59, Mayıs, 2018
Dokuz Eylul University-Faculty of Engineering Journal of Science and Engineering Volume 20, Issue 59, May, 2018

DOI: $10.21205 /$ deufmd.2018205950

\title{
Mineralogical and petrographic study of zeolitic tuffs from Yenice- Saraycık (Demirci, Manisa), Turkey
}

\section{Hülya KAÇMAZ}

Dokuz Eylül Üniversitesi, Mühendislik Fakültesi, Jeoloji Mühendisliği Bölümü, 35370, İzmir (ORCID: 0000-0001-7752-0408)

(Alınış / Received: 10.01.2018, Kabul / Accepted: 23.02.2018, Online Yayınlanma / Published Online: 15.05.2018)

Keywords

Zeolite, tuff, alteration, petrography, mineralogy
Abstract: The mineralogical and petrographic properties of the zeolitic tuffs around the Yenice-Saraycik, southwestern of Demirci (Manisa), were studied by using the polarizing microscope and powder X-ray diffraction (PXRD). Microscopic observations revealed that the tuffs are dominated volcanic glass however, contain small amounts of crystal and rock fragments. The crystal fragments consist mainly of quartz, k-feldspar, plagioclase and trace amounts of biotite. The glassy tuffs were altered to zeolites and other minerals.

PXRD analysis of the tuff samples supports the microscopic observations. The PXRD results showed that the tuffs are mainly altered to zeolite minerals, clinoptilolite-heulandite. Smectite is the most common clay mineral coexisting with zeolites. However, kaolinite and/or chlorite were detected in some zeolitic tuff examined. Quartz, plagioclase, K-feldspar and mica/illite were determined in the most of samples. Additionally, opal-CT was found together with kaolinite/chlorite in zeolitic tuffs near the Saraycık area.

\section{Yenice-Saraycık (Demirci, Manisa) civarındaki zeolitik tüflerinin mineralojik ve petrografik incelenmesi}

\begin{abstract}
Anahtar Kelimeler Özet: $\mathrm{Bu}$ çalıșmada Demirci'nin (Manisa) güney batısında, Zeolit, tüf, Yenice-Saraycık civarındaki zeolitik tüflerin mineralojik ve petrografik özellikleri polarizan mikroskop ve X-ışını alterasyon, petrografi, mineraloji difraktometre (XRD) yöntemleri kullanılarak incelenmiştir. Mikroskobik gözlemler tüflerin camsı yapıda olduğunu, bununla birlikte az miktarda kristal ve kaya parçaları içerdiğini göstermektedir. Kristaller kuvars, plajiyoklaz, potasyum feldispat ve az miktarda biyotittir. Camsı özellik gösteren tüfler zeolitlere ve bazı diğer minerallere dönüşmüştür.
\end{abstract}


Tüf örneklerinde yapılan XRD analizleri mikroskobik çalışmaları destekler niteliktedir. XRD çalışmaları tüflerin yaygın olarak klinoptilolit-höylandit gibi zeolit minerallerine dönüştügünü göstermektedir. Smektit tüf örneklerinde zeolitlerle birlikte görülen en yaygın kil mineralidir. Bununla birlikte bazı tüf örneklerinin kaolinit ve/veya klorit içerdiği belirlenmiştir. Örneklerin birçoğunda kuvars, potasyum feldispat, plajiyoklaz ve mika/illit saptanmıștır. Saraycık bölgesi civarındaki zeolitik tüflerde kaolinit/klorit ile birlikte Opal-CT mineraline rastlanmıştır.

Corresponding author: hulya.kacmaz@deu.edu.tr

\section{Introduction}

Zeolites are microporous, hydrated aluminosilicate minerals. They occur most commonly in volcanoclastic sediments, especially altered vitric tuffs. [1]. The Neogene volcano-sedimentary units containing zeolites are widely located in Western Turkey. The presence of zeolites within these units is mostly associated with altered tuffs [2-4].

The volcano-sedimentary units are commonly exposed in the Demirci (Manisa) area, Western Turkey. Recently, a study on tuffs around southwestern part of the Demirci, Yenice-Saraycık area, was carried out [5] and the geochemical characteristics of the tuffs have been described in detail. The purpose of this study is to define the mineralogical and petrographic features of the zeolitic tuffs around Yenice-Saraycık area.

\section{Geologic setting}

The study area, Yenice-Saraycık, is located in the southwestern part of the Demirci (Manisa) area (Figure 1). The main rocks outcropping in the study area are the Neogene fluvio-lacustrine sediments, Mesozoic carbonate rocks and Metamorphic rocks of the Menderes massif (Figure 2). The Menderes Massif metamorphic rocks form the basement rocks of the studied area. The recrystallized limestones of Mesozoic overlie the basement metamorphic rocks. These units are overlain unconformably by the Neogene sediments of fluvial, lacustrine mainly consisting of sandstone, conglomerate, siltstone, mudstone alternations and limestone, marl, shale and claystone alternations [6].

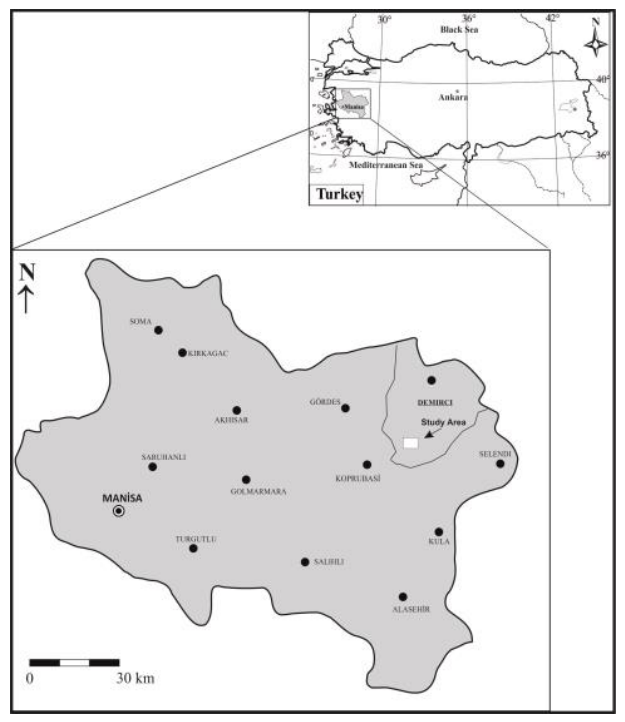

Figure 1. Location map of the study area.

The main rocks outcropping in the study area are the Neogene fluvial and lacustrine sediments. The tuffs studied here are intercalated with the fluviolacustrine sediments of Neogene. They have nearly horizontal layers and are 
generally white, yellowish white or cream-colored. The geochemical studies [5] show that the tuffs are peraluminous, calc-alkaline and also rhyolitic and rhyodacitic in composition.

\section{Material and Method}

The tuff samples collected from YeniceSaraycık (Demirci) area were investigated by using polarizing microscope and standard X-ray diffraction (XRD) analyses. Thin sections of tuff samples were prepared at Dokuz Eylul University. The petrographic examination was performed by polarizing microscope on selected thin sections. The mineralogy of the bulk samples was determined by X-ray diffraction (XRD) analysis. For the XRD analysis, pulverized powders were scanned from $4^{\circ}$ to $65^{\circ} 2 \theta$ at a speed of $2 \%$ min using $\mathrm{CuK \alpha}$ radiation.

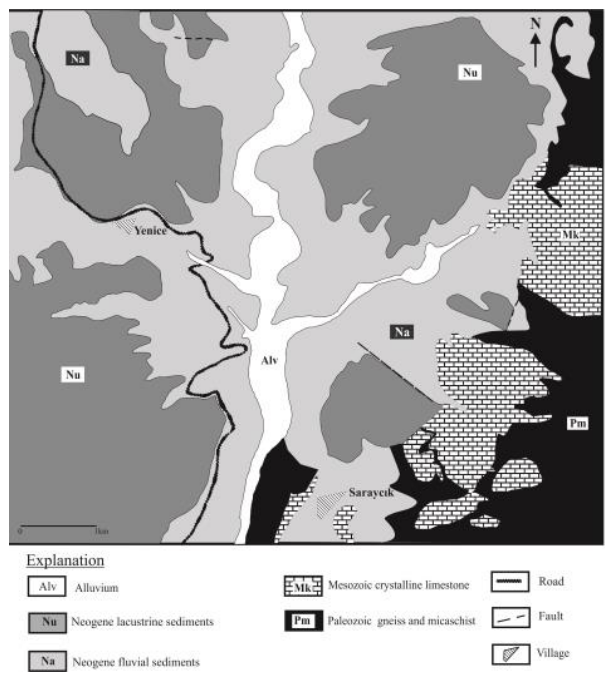

Figure 2. Simplified geological map of the study area. Modified from [6].

\section{Results and Discussion}

Tuff is consolidated volcanic ash. They contain mainly glass, crystal and rock fragments. The percentages of these fragments are used in naming the tuffs as vitric, crystal or lithic [7]. Microscopic studies reveal that the studied tuffs are made up of abundant proportions of glassy fragments. However, crystal and rock fragments are generally less than 10 percent of the tuff, so that the tuffs in the study area are classified as 'vitric tuffs'.

The glassy fragments are observed both as pumice fragments and glass shards (Figure $3 \mathrm{a}$ and $3 \mathrm{~b}$ ). The glass shards have mostly angular, curved shapes. The shapes of the glass shards are considerably well preserved. The pumice fragments are generally elongate and flattened. They are colorless to lightbrown under plane polarized light and isotropic under cross polarized light. Some pumice fragments have been partly or wholly replaced by calcite (Figure $3 c$ and $3 \mathrm{~d}$ ). The rock fragments observed rarely consist mainly of volcanic and lesser metamorphic rock fragments (Figure 3e and 3f).

Various types of pyrogenic crystals are seen in the thin section. These crystals are chiefly alkali feldspar, plagioclase and quartz. The alkali feldspar phenocrysts are seen mostly rectangular in shape. Pyrogenic quartz is easily recognized by broken and angular clast or crystal. Also, microcrystalline forms of quartz are present (Figure 3g and 3h). Biotite and hornblende are occasionally observed under thin section. The presence of above minerals demonstrates that tuffs were mainly felsic in composition. Likewise, the mineralogical composition of tuff is compatible with their chemical composition reported as rhyodaciticrhyolitic by [5]. Besides, the presence of glass shards together with euhedral or broken phenocrysts, especially of quartz and feldspar indicate that the tuffs were formed from explosive eruption [8]. 

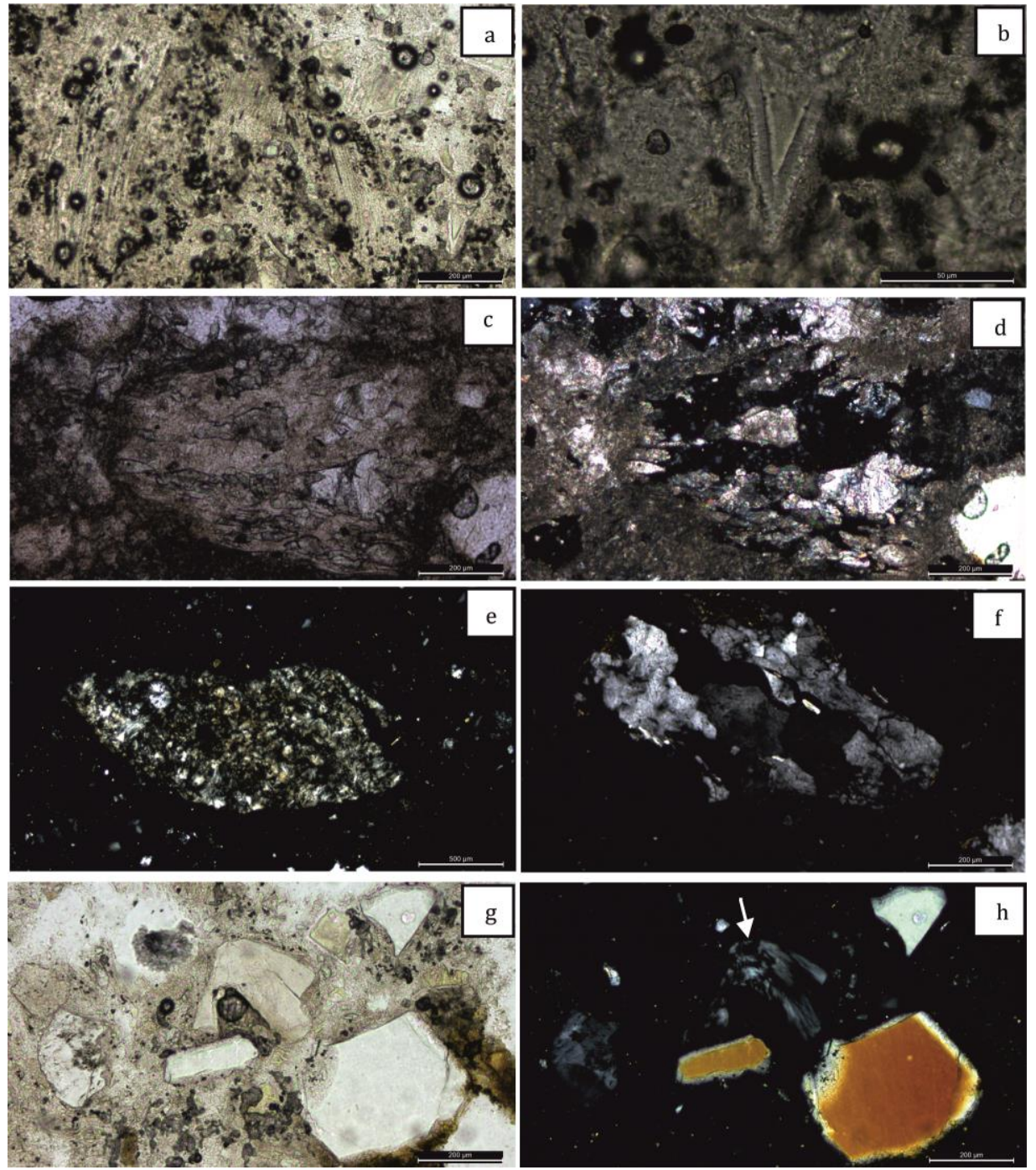

Figure 3. Thin section photographs of tuffs illustrating various pyroclasts and textures.

a) Pumice and glass shards in the matrix (plane polarized light). b) Close-up view of glass shard seen in the lower right corner of figure 3a. $\mathrm{c}$ and d) Calcite as a replacement product of pumice fragment (plane polarized and cross polarized light, respectively). e) Volcanic rock fragment (cross polarized light). f) Metamorphic rock fragment (cross polarized light). g and h) Quartz and feldspar together with microcrystalline silica (plane polarized and cross polarized light, respectively). Fibrous texture under cross polarized light suggests that microcrystalline silica is chalcedony (white arrow). 
XRD analyses indicate the presence of zeolite and clay minerals in tuffs of the study area. Zeolites, clinoptiloliteheulandite, are the predominant and mostly coexists with smectite. Other minerals found together with zeolites are quartz, k-feldspar, plagioclase, mica/illite and calcite. Opal-CT and kaolinite and/or chlorite were determined in only the zeolitic tuffs near the Saraycik area. A representative XRD powder data of bulk samples was given at Figure 4 .

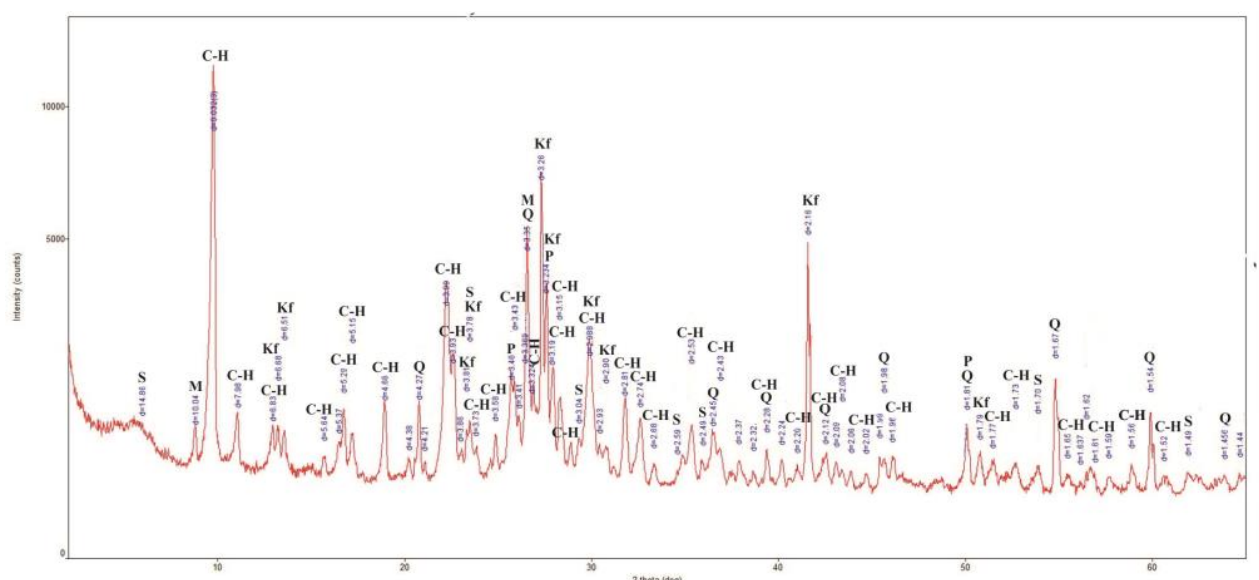

Figure 4. A representative powder $\mathrm{X}$-Ray diffraction pattern of the tuff samples. (C-H= clinoptilolite-heulandite, $\mathrm{S}=$ smectite, $\mathrm{M}=$ mica/illite, $\mathrm{P}=$ plagioclase, $\mathrm{Q}=$ quartz, $\mathrm{Kf}=\mathrm{k}$-feldspar).

It is known that volcanic glass is readily altered and replaced during diagenesis and the most common alteration products are zeolites and clays [9]. Likewise, zeolites formed from alteration of volcanic glass are frequently reported [10-13]. The vitric fragments being replaced by zeolite minerals are clearly seen under polarizing microscope in this study (Figure 5). In the figure $5 \mathrm{a}$, the clinoptilolite-heulandite appears to occur on the inner rim of glass shards. Also, in a few samples, acicular crystal clusters were observed to coexist with clinoptilolite-heulandite (Figure 5b and $5 \mathrm{c}$ ). Based on crystal outline, these are assumed to be mordenite.
According to the [1], the chemical composition of the parent rock controls the zeolite species. Clinoptilolite-heulandite type zeolites are commonly found in silica-rich rocks. Further, [14] noted that zeolites like clinoptilolite and mordenite occur in the Nuldaeri tuff having silicic composition $\left(\mathrm{SiO}_{2}\right.$ 62-72 wt. \%) in Yeongil Area (Korea). The existence of silica-rich zeolites, clinoptiloliteheulandite type, suggests that the studied tuffs are silica-rich. This suggestion is coherent with the study of [5], who reported high $\mathrm{SiO}_{2}$ contents $(>60$ wt. \%) in tuffs of the study area. 


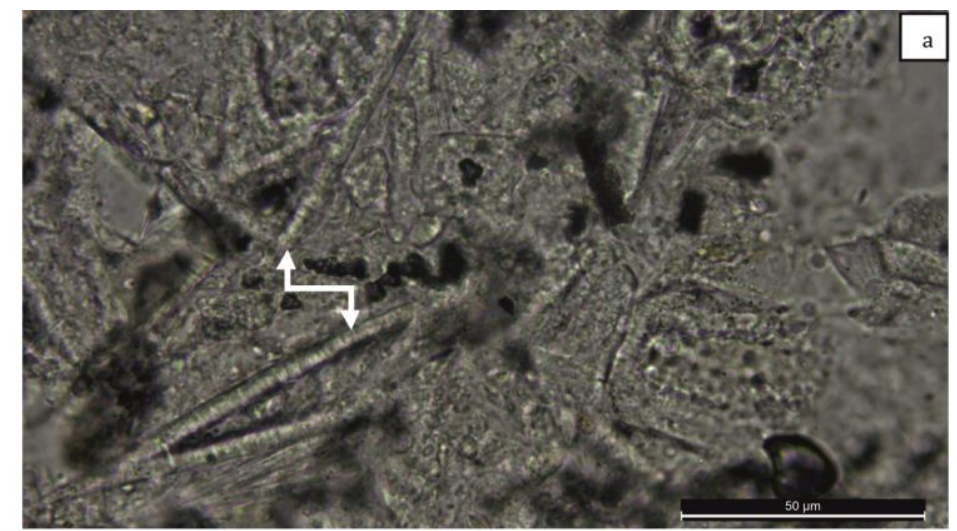

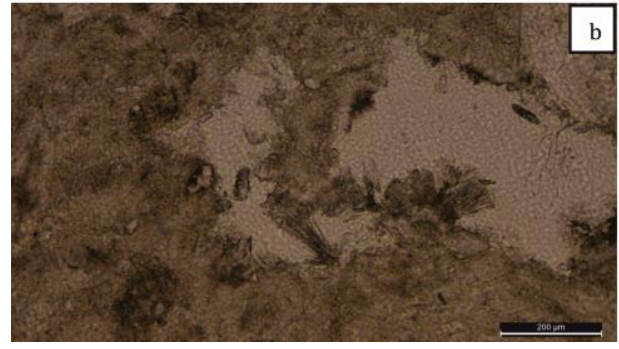

Figure 5. Thin section photomicrographs showing zeolitized glass in tuffs of study area. a) Glass shards (white arrows) replaced by zeolites, clinoptiloliteheulandite (plane polarized light). b) Pumice glass replaced by zeolites (plane polarized light). c) A close up view of the figure $5 \mathrm{~b}$ center. The black arrows indicate crystals of clinoptilolite-heulandite. Also, a cluster of acicular crystals seen in this figure are possibly mordenite.

\section{Conclusion}

The mineralogical and petrographic study of zeolitic tuffs from YeniceSaraycık area (Demirci-Manisa) showed that the tuffs contain abundant glassy fragments. Much of the glassy fragments have been altered to zeolite minerals and clays. The principal zeolite minerals in tuffs are clinoptilolite-heulandite.

The abundance of glassy materials and also silicic composition of the original tuffs are the major factors governing

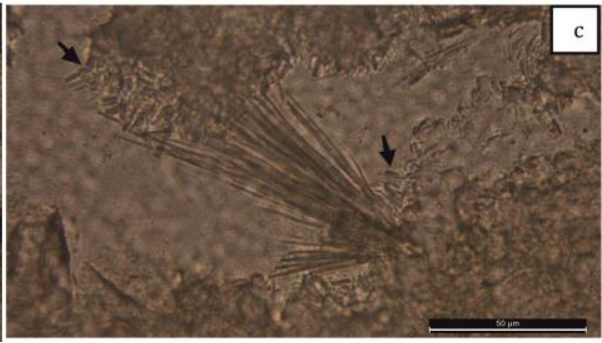

the zeolitization process and zeolite species in the studied area.

\section{Acknowledgment}

Author thanks the Dokuz Eylul University for providing laboratory facilities during this study.

\section{References}

[1] Iijima, A. 1980. Geology of natural zeolites and zeolitic rocks, Pure and Appl. Chem. vol 52, page 2115-2130.

[2] Kacmaz, H. and Kokturk, U. 2004. Geochemistry and mineralogy of zeolitic tuffs from Alacati (Cesme) area, Turkey. Clays Clay Miner. 52, 705-713.

DOI:10.1346/CCMN.2004.052060 5

[3] Esenli, F. 1993. Gördes Neojen havzasının asitik tüflerinde zeolitleşme (hoylanditklinoptilolit tip) ile meydana 
gelen kimyasal değișimler. Türkiye Jeoloji Bülteni, 36/2, 3744.

[4] Gundogdu, M.N., Yalcin, H., Temel, A., Clauer, N. 1996. Geological, mineralogical and geochemical characteristics of zeolite deposits associated with borates in the Bigadiç, Emet and Kırka Neogene lacustrine basins, Western Turkey. Mineral. Deposita 31, 492-513.

[5] Kacmaz, H. 2016. Major, trace and rare earth element (REE) characteristics of tuffs in the Yenice-Saraycık area (Demirci, Manisa), Western Anatolia, Turkey. 168, 169-176. DOI: 10.1016/j.gexplo.2016.06.014

[6] Maden Tetkik Arama, MTA. 1976. Koprubasi Bolgesi Uranyum yataklarına ait rapor. MTA Enstitusu, Radyoaktif Mineraller ve Komur Dairesi Baskanlıgı, Radyoaktif Mineraller Arama Servisi, Ankara.

[7] Pettijohn, F.J. 1957. Sedimentary Rocks, 2nd edition. Harper and Row, New York.

[8] Fastovsky, D.E., Hermes, O.D., Strater, N.H., Bowring,S.A., Clark, J.M., Montellano, M., and Hernández, R.,R. 2005. Pre-Late Jurassic, fossil-bearing volcanic and sedimentary red beds of Huizachal Canyon, Tamaulipas, México, in Anderson, T.H., Nourse, J.A., McKee,J.W., and Steiner, M.B., eds., The Mojave-Sonora Megashear Hypothesis: Development, Assessment, and Alternatives: Geological Society of America Special Paper 393, p. 401-426.

[9] Tucker, M.E. 2001. Sedimentary Petrology: An Introduction to the Origin of Sedimentary Rocks, 3rd Edition, Wiley-Blackwell, 272 pages.
[10] Hay R.L. 1986. Geologic occurrence of zeolites and some associated minerals. Pure \& Appl. Chem., Vol. 58, No. 10, page. 1339-1342. DOI: 10.1351/pac198658101339

[11] Ghiara, M.R., Petti, C., Franco, E., Lonis, R., Luxoro, S. And Gnazzo, L. 1999. Occurrence of clinoptilolite and mordenite in Tertiary calc-alkaline pyroclastites from Sardinia (Italy). Clays and Clay Minerals, 47, 319-328. DOI: 10.1346/CCMN.1999.0470308

[12] Cocheme, J.-J., Leggo, P.J., Damian, G., Fulop, A., Ledesert, B. and Grauby, 0, 2003. The mineralogy and distribution of zeolitic tuffs in the Maramures Basin, Romania. Clays and Clay Minerals, 51, 599 608.

DOI: 10.1346/CCMN.2003.0510602

[13] Brathwaite, R.L. 2003. Geological and mineralogical characterization of zeolites in lacustrine tuffs, Ngakuru, Taupo Vocanic Zone, New Zealand. Clays and Clay Minerals, 51,589-598. DOI: $\quad 10.1346 / C C M N$. 2003.0510601

[14] Noh, J.H. and Kim, S.J. 1986. Zeolites from Tertiary tuffaceous rocks in Yoengil area, Korea. in New developments in zeolite science and technology, 28,. Proc. of the Seventh Int. Zeol. Conf., ed. Murakami, Y., Iijima, A., and Ward, J.W., Kondansha and Elsevier, Tokyo, 59-66. 